\title{
Educational Environment for Undergraduate Medicine and Nursing Programme at Eastern University, Sri Lanka; Students' Perceptions
}

\author{
P. Youhasan* and T. Sathaananthan \\ Department of Medical Education \& Research, Eastern University of \\ Sri Lanka
}

\begin{abstract}
Educational environment directly influences the learning process and allows the students to pay more attention on learning. This study was aimed to assess the students' perceptions on the educational environment at Faculty of Health-Care Sciences, Eastern University, Sri Lanka (FHCS, EUSL). This survey was performed on academic year 2014/2015 with the use of Dundee Ready Education Environment Measure (DREEM) questionnaire. 156 (114 Medical \& 42 Nursing) students participated. The scores of perception statements were converted into continuous variables and summarized as means. T-test was used to compare students' perception between programme of study. The results revealed that as per the DREEM analysis, the learning was perceived more positive $(27 / 48)$, the teaching was moving in the right direction $(24 / 44)$ and the academic self-perceptions was felt more on the positive side (19/32). However, there were many issues in atmosphere $(24 / 48)$ and the social self-perception was also not too bad $(16 / 28)$. The overall DREEM mean score was 111 out of 200, which indicates that there was a more positive educational environment than negative in FHCS, EUSL. Furthermore, students identified problems with regard to the supportive system when they got stressed and relax learning atmosphere during lecture $\&$ tutorial. Hence, the faculty needs to identify strategies to improve weaker areas which were identified in the study. Subsequent studies should
\end{abstract}

${ }^{*}$ Correspondence should be addressed to P. Youhasan, Department of Medical Education \& Research, Faculty of Health-Care Sciences, Eastern University, Sri Lanka (Email: yuga_p@hotmail.com) 
be conducted in future to assess the results of the corrective strategies and further exploration.

Keywords: Education environment, faculty of health-care sciences eastern university, medicine, nursing, dreem questionnaire.

\section{Introduction}

Education environment is one of most important factors determining the learning process (Roff \& McAleer, 2001). It affects the learner motivation and engagement on learning (Hutchinson, 2003). Effective educational environment positively correlates with the optimal outcome of an educational institution (Abdulrahman, 2013).

Education environment is an indispensable part of the curriculum, affecting the interaction between student, methods, assessment, and educational outcomes (Palmgren \& Chandratilake, 2011). Therefore, assessing the educational environment is important to identify the problematic areas in a particular institution. It would assist the curriculum planner to do the necessary adjustment to achieve the optimal educational outcome. In this regards, internationally and nationally, several studies were carried out to measure the educational environment with the use of Dundee Ready Education Environment Measure (DREEM). DREEM is a globally accepted tool to measure the education environment in medical and allied health institutions (Khan et al., 2011).

At present, there are ten state universities conducting health professional degree programmes in Sri Lanka, namely; University of Colombo, University of Sri Jayewardenepura, University of Peradeniya, University of Kelaniya, University of Jaffna, University of Ruhuna, Eastern University, Rajarata University, Open University, Sri Lanka and Sir John Kotalawala Defense University. Among these, several universities have been assessed their education environment.

Faculty of Health-Care Sciences (FHCS) is the youngest faculty of the Eastern University, Sri Lanka (EUSL). It was established on 2005. There are two programme being conducted by the faculty, namely; Bachelor of Medicine, Bachelor of Surgery (MBBS) and Bachelor of Science in Nursing [BSc.(N)]. FHCS is one of the medical faculties in Sri Lanka following the spiral model, integrated, modular curriculum. Curriculum and Educational environment influences the effectiveness of education. The curriculum and its delivery are 
periodically monitored by the faculty but education environment is not regularly assessed. Thus, this study was aimed to assess the students' perception of the educational environment at the FHCS, EUSL. The findings of this study could be used as a basis to support curriculum planners at FHCS to improve the medicine and nursing programme and also it will serve as a longitudinal first review evidence to support future study at FHCS.

\section{Review of Literature}

\section{Education Environment}

The educational environment is defined as everything that happens within the classroom, department, faculty or university which is crucial in determining the success of undergraduate medical education (Genn, 2001; Roff \& McAleer, 2001). It is synonymous with climate, atmosphere or ambiance, which is multifaceted and can be described as an educational institution's personality, spirit, and culture (Palmgren \& Chandratilake, 2011).

\section{Influence of Educational Environment on Learning}

Engaging the students on learning is the ultimate goal of education. There are many factors which influence on learning (Figure 1). Learning mainly depends on learners' motivation and their perception of relevance. These, in turn, can be affected by the learners' previous experiences, preferred learning styles, context and environment in which the learning is taking place (Hutchinson, 2003). Education environment is one of the most important factors to determine the effective curriculum. Educational outcome may vary among the institutions where the curriculum remains the same because of the educational environment changes from one institution to another (Khan et al., 2011).

\section{Maximizing the Educational Environment}

The curriculum designers of the programme should consider the suitability of the learning environment to potentiating learning. The teaching methods should build on learners' experience, creating a collaborative environment. In longer courses, student support systems and informal activities that build collective identity must be considered. Room temperature, comfort of seating, background noise, and visual distractions are the physical factors that need to be considered in designing the classroom. Clinical setting is an important environment for health-care students. Arranging adequate space, and assigning students' roles in clinical setting are crucial 
tasks of programme planners. The dual role of teacher and clinician can be complicated. The students will be closely observing the clinician and picking up hidden messages about clinical practice. They need to feel that there is no danger that they will unnecessarily distress or harm patients or their families. They also need to feel safe from humiliation (Hutchinson, 2003).

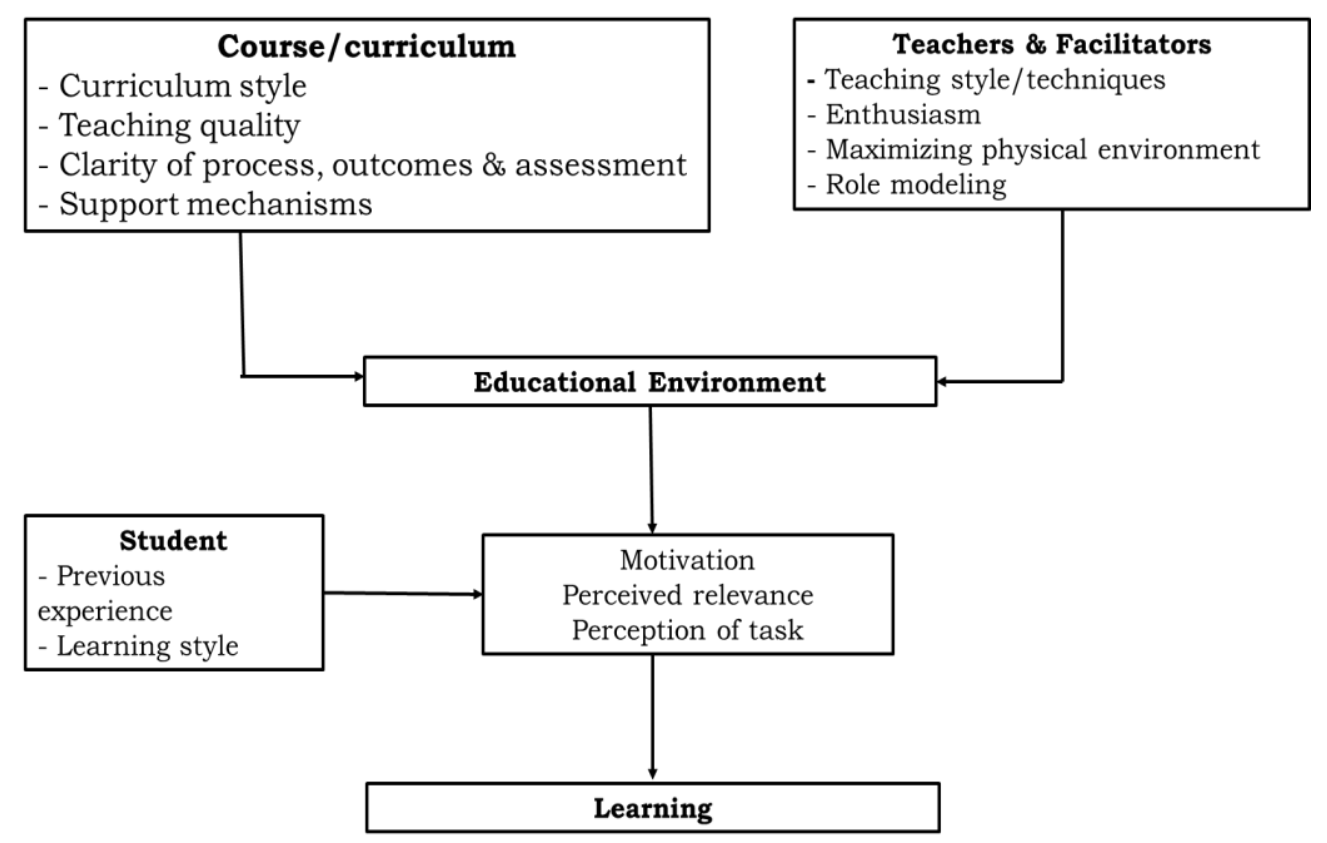

Figure 1. Factors influence on learning(Hutchinson, 2003).

\section{Measuring the Education Environment}

There are several instruments available to measure the medical education environment. Roff et al. (1997) developed the Dundee Ready Education Environment Measure (DREEM) with a panel of nearly 100 medical educators and 1000 students to measure and 'diagnose' undergraduate educational climates in the health professions. It is a generic, multidimensional, multicultural instrument validated and used in developed and developing countries with considerable success in profiling the perceived weaknesses and strengths of medical and allied institutions (Khan et al., 2011). It allows quality assurance comparisons to be made between courses as well as within components of a course (Roff \& 
McAleer, 2001; Roff, 2005).

DREEM inventory consists of 50 questions, each scoring 4, thus giving a cumulative maximum individual DREEM score of 200. The scores are, 4-strongly agree, 3-agree, 2-unsure, 1-disagree and 0strongly disagree. Items with a mean score of 3 and above are considered positive and items with a mean score of 2 and below are considered as problem areas and were identified in the study population. Items with a mean score between 2 and 3 are considered as aspects of the educational environment that require enhancement. The following is an approximate guide to interpreting the overall score: 0-50 Very Poor, 51-100 Plenty of Problems and 101-150 More Positive than Negative, 151-200 Excellent (Roff et al., 1997).

The inventory consists of five subscales namely perceptions of learning, perceptions of teaching, self-academic perceptions, perceptions of atmosphere and social self-perceptions. The scores for each subscale were interpreted on a four-tiered scale as mentioned in below.

Students' Perception of Learning: 0-12 Very Poor; 13-24 Teaching is viewed negatively; 25-36 A more positive perception; 37-48 Teaching highly thought of. Students' Perception of Teachers: 0-11 Abysmal; 12-22 In need of some retraining; 23-33 Moving in the right direction; 33-44 Model course organizers. Students' Academic SelfPerception: 0- 8 Feelings of total failure; 9-16 Many negative aspects; 17-24 Feeling more on the positive side; 25-32 Confident. Students' Perceptions of Atmosphere: 0-12 A terrible environment; 13-24 There are many issues which need changing; 25-36 A more positive; 37-48 A good feeling overall. Students' Social Self Perceptions: 0-7 Miserable; 8-14 Not a nice place; 15-21 Not too bad; 22-28 Very good socially (Roff et al., 1997).

\section{Medical Educational Environment Measured by DREEM}

A Pakistan study revealed that DREEM score of the private medical institution $(X=137)$ was significantly higher than in the public sector $(\mathrm{X}=115)$ (Khan et al., 2011).

First year students $(119 / 200)$ were satisfied with the learning environment compared to the clinical batch student (114/200) at Melaka Manipal Medical College, India (Abraham et al., 2008).

Educational environment in the Qassim University Medical College, Saudi Arabia was more positive than negative (112/200). There were 
no significant differences of perceptions between genders and phases of the programme (Abdulrahman, 2013).

339 students from pre, para \& clinical phases in Faculty of Medical Sciences, University of Sri Jayewardenepura (FMS/USJ) participated in a study to measure the education environment. Overall DREEM score was 108. Students' perception on teachers, Self-academic and self-social perceptions were significantly different among the phases (Jiffry et al., 2005).

A majority (65.6\%) of students in University of Colombo, Faculty of Medicine (UCFM) stated that the education environment in the UCFM was 'more positive than negative' (107/200) to the DREEM inventory (Lokuhetty et al., 2010).

Nursing students perceived relative satisfaction with the educational environment in University of Ruhuna and they also identified problematic areas that need improvement (Manjula \& Chandana, 2012).

\section{Methodology}

It was a descriptive cross-sectional study conducted in FHCS, EUSL during the academic year of 2014/2015. Final year and year prior to final year medical and nursing students were selected as the study population. Non-probability sampling method was used to collect convenience samples from study population.

Self-administered DREEM questionnaire was used to collect perception data from students. All questionnaires were coded and entered into an electronic database. The scores for the statements relating to negative attributes were computed in the reverse order. Data analysis was carried out using SPSS version 22. Descriptive statistics were computed to present distribution of study participants by student's programme of study. T-test was used to compare students' perception between the programme of study. Ethical clearance was obtained from the ethics review committee of FHCS, EUSL. 


\section{Findings}

There were 156 students of FHCS, EUSL who participated in this study. They consisted of 114 and 42 students in MBBS and BSc in nursing programme respectively. There were 95 females in the study group. The total mean DREEM score was 111 out of 200, which indicates that there was "more positive educational environment than negative" in FHCS, EUSL. (Table 1).

Most of the students had a positive perception about learning at FHCS, EUSL (Table 1). However, enhancement requires to determine student centered learning. Nursing students identified a problem; they were not clear about the learning objectives of the course. Nursing students had high likelihood perception in teaching which helped to develop their competencies and teaching time put for good use (Table 2).

The students' perception on teachers' was in right direction (Table 1). Students perceived problems among teachers' role on affective changes during teaching session. The overall students' perception on the teachers' effective communication was significantly different among course (Table 2).

Table 1. MBBS \& BSc(N) students' perception of education environment in FHCS, EUSL and its interpretation

\begin{tabular}{|c|c|c|c|c|}
\hline \multirow{2}{*}{$\begin{array}{l}\text { Areas of students' } \\
\text { perception }\end{array}$} & \multicolumn{3}{|c|}{ DREEM Mean $(X)$} & \multirow[b]{2}{*}{ Interpretation } \\
\hline & MBBS & BSc.(N) & $\begin{array}{c}\text { Overall } \\
\text { (S.D) }\end{array}$ & \\
\hline $\begin{array}{l}\text { 01. Students' Perceptions } \\
\text { on Learning }\end{array}$ & 27.11 & 27.50 & $\begin{array}{l}27.21 \\
(6.78)\end{array}$ & $\begin{array}{l}\text { More positive } \\
\text { perception }\end{array}$ \\
\hline $\begin{array}{l}\text { 02. Students' Perceptions } \\
\text { on Teachers }\end{array}$ & 23.80 & 24.81 & $\begin{array}{l}24.07 \\
(4.92)\end{array}$ & $\begin{array}{l}\text { Moving in the right } \\
\text { direction }\end{array}$ \\
\hline $\begin{array}{l}\text { 03. Students' academic } \\
\text { self-perception }\end{array}$ & 18.80 & 20.76 & $\begin{array}{l}19.33^{*} \\
(4.64)\end{array}$ & $\begin{array}{l}\text { Feeling more on } \\
\text { the positive side }\end{array}$ \\
\hline $\begin{array}{l}\text { 04. Students' Perceptions } \\
\text { on Atmosphere }\end{array}$ & 23.91 & 24.98 & $\begin{array}{l}24.20 \\
(7.42)\end{array}$ & $\begin{array}{c}\text { There } \\
\text { are many issues } \\
\text { which need } \\
\text { changing }\end{array}$ \\
\hline $\begin{array}{l}\text { 05. Students' Social Self } \\
\text { Perceptions }\end{array}$ & 14.69 & 16.38 & $\begin{array}{l}15.54^{*} \\
(4.32)\end{array}$ & $\begin{array}{c}\text { Social life is Not too } \\
\text { bad }\end{array}$ \\
\hline
\end{tabular}




\section{Overall Perception}

\begin{tabular}{llcc}
108.31 & 114.43 & $\begin{array}{c}\text { More Positive } \\
111.37 \\
(5.02)\end{array}$ & $\begin{array}{c}\text { environment than } \\
\text { Negative }\end{array}$ \\
\hline
\end{tabular}

* Significant p-value, S.D - Standard deviation

Students' academic self-perception was more on the positive side (Table 1). Learning strategies, problem solving skills and career relevant learning were significantly different among courses. However, both groups of students had problems in being able to memorize all they need (Table 2). Students' perceived social life in the faculty was not too bad (Table 1). Also they identified problems with the good support system for students who get stressed (Table 2). There were many issues found by students' perception on learning atmosphere (Table1). The students have perceived problems on relax learning atmosphere during lecture or tutorials, learning atmospheric motivation and course timetable (Table 2).

\section{Discussion}

Education environment at FHCS was assessed by the study after nine years of its establishment. DREEM was used to assess the educational climate. This tool is globally recognizable to assess the educational environment at medical institutions.

This study revealed that overall student perception about education environment at FHCS, EUSL was "More Positive environment than Negative". This finding coincided with the earlier studies which were conducted in different universities in Sri Lanka. Education environment of UCFM was perceived as positive $(107 / 200)$ by a majority of students (Lokuhetty et al., 2010). Students had positive perception about education environment (107/200) at FMS/USJ (Jiffry et al., 2005). Furthermore, nursing students felt relative satisfaction with the perceived environment (109/200) at University of Ruhuna (Manjula \& Chandana, 2012). The above mentioned DREEM scores obtained in Sri Lankan studies were less favorably compared with the total mean scores achieved in University of Dundee (139/200) (Al-Hazimi et al., 2004), Birmingham Medical School (139/200) (Varma, Tiyagi \& Gupta, 2005), Koirala Institute of Health Sciences, Dharan, Nepal (130/200) (Roff et al., 2001).

Nursing students' overall perception (114/200) about education environment at FHCS, EUSL was high compared to the medical students $(108 / 200)$. Among the 50 items on the DREEM inventory, 37 items had a mean score between 2.00 to 3.00. These items are 
aspects of the educational environment that could be enhanced. A total of 16 items scored below 2.00. These could be identified as problem areas in FHCS educational environment that require further improvements. Furthermore, no item received a mean score of three or more, which indicates that students have not perceived satisfaction with any item. Student gave the highest rating (2.88) to the statement of; "The teachers are knowledgeable". Meanwhile lowest rating (1.43) went to "The course is well timetabled".

Table 2. Mean score for the DREEM among Students' perception of education environment at FHCS, EUSL.

\begin{tabular}{|c|c|c|c|}
\hline \multirow{2}{*}{ Statements of Students' Perceptions } & \multicolumn{3}{|c|}{ DREEM Mean (X) } \\
\hline & MBBS & BSc. (N) & Overall \\
\hline \multicolumn{4}{|l|}{ Students' Perceptions about learning } \\
\hline $\begin{array}{l}\text { I am encouraged to participate in teaching } \\
\text { sessions }\end{array}$ & 2.54 & 2.95 & 2.75 \\
\hline The teaching is often stimulating & 2.58 & 2.55 & 2.56 \\
\hline The teaching is student centered & 2.46 & 2.71 & 2.59 \\
\hline The teaching helps to develop my competence & 2.44 & 2.83 & 2.64* \\
\hline The teaching is well focused & 2.15 & 2.48 & 2.31 \\
\hline The teaching helps to develop my confidence & 2.29 & 2.31 & 2.30 \\
\hline The teaching time is put to good use & 2.09 & 2.29 & 2.19* \\
\hline The teaching over emphasizes factual learning & 1.74 & 1.40 & 1.57 \\
\hline $\begin{array}{l}\text { I am clear about the learning objectives of the } \\
\text { course }\end{array}$ & 2.23 & 1.86 & 2.04* \\
\hline $\begin{array}{l}\text { The teaching encourages me to be an active } \\
\text { learner }\end{array}$ & 2.43 & 2.26 & 2.35 \\
\hline $\begin{array}{l}\text { Long term learning is emphasized over short } \\
\text { term learning }\end{array}$ & 2.05 & 2.14 & 2.10 \\
\hline The teaching is too teacher centered & 2.11 & 1.71 & 1.91 \\
\hline \multicolumn{4}{|l|}{ Students' Perceptions about Teachers } \\
\hline The teachers are knowledgeable & 2.86 & 2.90 & 2.88 \\
\hline $\begin{array}{l}\text { The teachers espouse a patient centered } \\
\text { approach to consulting }\end{array}$ & 2.28 & 2.36 & 2.32 \\
\hline The teachers ridicule their students & 1.68 & 2.02 & 1.85 \\
\hline The teachers are authoritarian & 1.55 & 1.43 & 1.49 \\
\hline $\begin{array}{l}\text { The teachers appear to have effective } \\
\text { communication skills with students }\end{array}$ & 2.33 & 2.69 & $2.51 *$ \\
\hline
\end{tabular}


The teachers are good at providing feedback to students

$\begin{array}{lll}2.17 & 2.19 \quad \mathbf{2 . 1 8}\end{array}$

The teachers provide constructive criticism here

The teachers give clear examples

$\begin{array}{ll}1.75 & 2.07\end{array}$

1.91

The teachers get angry in teaching sessions

2.33

2.50

2.42

2.06

1.74

1.90

The teachers are well prepared for their teaching sessions

$2.58 \quad 2.43 \quad \mathbf{2 . 5 0}$

The students irritate the course teachers
2.48

2.33

\section{Students' Perceptions about Academic Self-Perception}

\begin{tabular}{|c|c|c|c|}
\hline $\begin{array}{l}\text { Learning strategies which worked for me } \\
\text { before continue to work for me now }\end{array}$ & 2.49 & 2.95 & $2.72 *$ \\
\hline I am confident about passing this year & 2.69 & 2.71 & 2.70 \\
\hline $\begin{array}{l}\text { I feel I am being well prepared for my } \\
\text { profession }\end{array}$ & 2.47 & 2.64 & 2.56 \\
\hline $\begin{array}{l}\text { Last year's work has been a good preparation } \\
\text { for this year's work }\end{array}$ & 2.29 & 2.60 & 2.44 \\
\hline I am able to memorize all I need & 1.96 & 1.64 & 1.80 \\
\hline $\begin{array}{l}\text { I have learned a lot about empathy in my } \\
\text { profession }\end{array}$ & 2.39 & 2.69 & 2.54 \\
\hline $\begin{array}{l}\text { My problem solving skills are being well } \\
\text { developed here }\end{array}$ & 2.18 & 2.67 & 2.43* \\
\hline $\begin{array}{l}\text { Much of what I have to learn seems relevant } \\
\text { to a career in healthcare }\end{array}$ & 2.31 & 2.86 & $2.58 *$ \\
\hline \multicolumn{4}{|c|}{ Students' Perceptions about Social Self Perceptions } \\
\hline $\begin{array}{l}\text { There is a good support system for students } \\
\text { who get stressed }\end{array}$ & 1.62 & 1.69 & 1.66 \\
\hline I am too tired to enjoy this course & 2.06 & 2.36 & 2.21 \\
\hline I am rarely bored on this course & 1.69 & 2.14 & 1.92 \\
\hline I have good friends in this course & 2.73 & 2.88 & 2.80 \\
\hline My social life is good & 2.67 & 2.83 & 2.75 \\
\hline I seldom feel lonely & 1.93 & 2.10 & 2.01 \\
\hline My accommodation is pleasant & 1.99 & 2.38 & 2.19 \\
\hline
\end{tabular}

\section{Students' Perceptions about Atmosphere}

The atmosphere is relaxed during consultation teaching

$2.04 \quad 2.21 \quad \mathbf{2 . 1 2}$

The course is well timetabled

$\begin{array}{lll}1.40 & 1.45 \quad \mathbf{1 . 4 3}\end{array}$

Cheating is a problem in this course

$\begin{array}{lll}1.98 & 2.19 & \mathbf{2 . 0 9}\end{array}$

The atmosphere is relaxed during lectures

$\begin{array}{lll}1.68 & 1.83 \quad \mathbf{1 . 7 5}\end{array}$

There are opportunities for me to develop interpersonal skills

$2.20 \quad 2.26 \quad \mathbf{2 . 2 3}$




$\begin{array}{llll}\text { I feel comfortable in teaching sessions socially } & 2.19 & 2.29 & \mathbf{2 . 2 4} \\ \text { The atmosphere is relaxed during } & 1.86 & 1.83 & \mathbf{1 . 8 5} \\ \text { seminars / tutorials } & 2.25 & 2.21 & \mathbf{2 . 2 3} \\ \text { I find the experience disappointing } & 2.16 & 2.26 & \mathbf{2 . 2 1} \\ \text { I am able to concentrate well } & 2.00 & 2.26 & \mathbf{2 . 1 3} \\ \text { The enjoyment outweighs the stress of } & 1.94 & 1.83 & \mathbf{1 . 8 9} \\ \text { studying medicine } & 2.21 & 2.33 & \mathbf{2 . 2 7} \\ \text { The atmosphere motivates me as a learner } & & \end{array}$

the items in italics were negative questions, ${ }^{*}$ significant $p$ value

\section{Conclusions}

The present study revealed that, both groups of students perceived the learning environment at FHCS, EUSL was more positive than negative. Nevertheless, the study also revealed problematic areas of learning atmosphere. It is recommended that a suitable relaxed learning atmosphere at FHCS, EUSL must be established. A proper supportive system should be developed for the students who got stressed or bored on courses. Student centered learning must be determined in the faculty such as Problem Based Learning. Periodical feedback/programme must be initiated to develop students' attitude. Hence, faculty needs to identify the strategies to improve weaker and problematic areas which were identified in the study. Subsequent studies should be conducted in future to assess and/or monitor the results of the implemented strategies.

\section{References}

Abdulrahman, A. M. (2013). Perceptions of the educational environment of a new medical school, Saudi Arabia. International journal of health sciences, 7(2), 150-9. Retrieved from http://www.pubmedcentral.nih.gov/articlerender.fcgi? artid $=3883605 \&$ tool $=$ pmcentrez\&rendertype $=$ abstract https://doi.org/10.12816/0006039

Abraham, R., Ramnarayan, K., Vinod, P., \&Torke, S. (2008). Students' perceptions of learning environment in an Indian medical school.BMC Medical Education, 8, 20.doi:10.1186/1472-6920-8-20 https://doi.org/10.1186/1472-6920-8-20 
Genn, J. M. (2001). Curriculum, environment, climate, quality and change in medical education - a unifying perspective (Part 2). Medical Teacher, 23(5), 445-54.

https://doi.org/10.3109/01421590109177942 https://doi.org/10.1080/01421590120075661

Hutchinson, L. (2003). ABC of learning and teaching: Educational environment. Bmj, 326(7393), 810-812. https://doi.org/10.1136/bmj.326.7393.810

Jiffry, M., McAleer, S., Fernando, S., \& Marasinghe, R. (2005). Using the DREEM questionnaire to gather baseline information on an evolving medical school in Sri Lanka. Medical Teacher, 27(4), 348-352. https://doi.org/10.1080/01421590500151005

Khan, J. S., Tabasum, S., Yousafzai, U. K., \& Mukhtar, O. (2011). Measuring the Medical Education Environment in Undergraduate Medical Colleges Across Punjab, Pakistan, 27, $14-18$.

Lokuhetty, M. D., Wamakulasuriya, S. P., Perera, R. I., De Silva, H. T., \& Wijesinghe, H. D. (2010). Students' perception of the educational environment in a Medical Faculty with an innovative curriculum in Sri Lanka. South-East Asian Journal of Medical Education, 4(1), 9-16. Retrieved from http://thailand.digitaljournals.org/index.php/SEAJME/article/ view/4682

Manjula, H., \& Chandana, N. G., (2012). Evaluation of educational environment of Nursing Undergraduates. Galle Medical journal, $17(2), 19-25$.

Palmgren, P. J., \& Chandratilake, M. (2011). Perception of Educational Environment Among, 25(2), 151-163.

Roff, S., McAleer, S., Harden, R. M., Al-Qahtani, M., Ahmed, A. U., Deza, H., \& Groenen, G., (1997). Development and validation of the Dundee Ready Education Environment Measure (DREEM). Medical Teacher, 19(4), 295-299.

https://doi.org/10.3109/01421599709034208

Roff, S., \& McAleer, S. (2001). What is educational climate? Medical Teacher, 23(4), 333-334.

https://doi.org/10.1080/01421590120063312 
Roff, S., McAleer, S., Ifere, O., \& Bhattacharya, S. (2001). A global diagnostic tool for measuring educational environment: comparing Nigeria and Nepal. Medical Teacher, 23(4), 378-382. https://doi.org/10.1080/01421590120043080

Varma, R., Tiyagi, E., \& Gupta, J. K. (2005). Determining the quality of educational climate across multiple undergraduate teaching sites using the DREEM inventory. BMC Medical Education, 5(1), 8.doi:10.1186/1472-6920-5-8.

https://doi.org/10.1186/1472-6920-5-8

Received: 31-03-2016 Revised: 24-06-2016 Accepted: 07-07-2016 